\title{
Islamic Poems by Rukun Nasution (1928- 1998): Themes and Social Relevance
}

\author{
Yusnaili Budianti, Hasan Asari* \\ Universitas Islam Negeri Sumatera Utara Medan, Indonesia \\ *corresponding author: hasanasari@uinsu.ac.id \\ Received: 28-11-2021; Revised: 13-4-2021; Accepted: 4-5-2021 \\ DOI: $10.31291 / \mathrm{hn} . v 10 \mathrm{i} 1.592$
}

\begin{abstract}
This study analyzes two poems written by Rukun Nasution (1928-1998), namely Syair Pengajak Solat (Invitation to Prayer) and Doa/Syair Menjelang Pajar (Invocation/Poem before Dawn). This manuscript only came to the attention of the authors in 2018, and this is the first time the book of poetry is being studied and described. The main objective of this study is to analyze the content of the poems, with reference to their socio-religious relevance and some philological aspects. Rukun (the popular name of Rukun Nasution) wrote his poems in the 1960s using Latin script, and the fact he had no formal education other than a three-year of elementary school made his creative productivity more interesting. He presented his ideas in a well-structured text while applying the 'aa-aa' rhyme consistently. The poems contain Islamic messages, with prayer procedures being the most dominant theme. These poems are relevant to document religious information, disseminate Islamic teachings, while remains artistically creative.
\end{abstract}

Keywords: Islamic poems; Malay literature; Rukun Nasution 


\begin{abstract}
Abstrak
Dalam artikel ini dikaji dua syair karya Rukun Nasution (1928-1998): 1) Syair Pengajak Solat dan 2) Doa/Syair Menjelang Pajar. Naskah ini baru menjadi perhatian peneliti pada tahun 2018 dan untuk pertama kalinya diteliti, bahkan dideskripsikan melalui artikel ini. Fokus perhatian ada pada pemetaan muatan syair, namun juga memberi perhatian pada relevansi dari naskah serta sedikit sentuhan filologis. Naskah beraksara Latin dari tahun 1960an ini ditulis oleh seorang yang hanya menamatkan pendidikan formal Sekolah Dasar-fakta yang membuat kreativitasnya sedemikian menarik. Syair-syairnya menyajikan gagasan secara terstruktur dengan menggunakan rima 'aa-aa' yang sangat konsisten. Syair-syair Rukun Nasution mengandung informasi keagamaan, dengan topik paling dominan adalah Fikih Salat. Syair-syair ini memiliki relevansi sosial, karena fungsinya mendokumentasikan informasi keagamaan, sebagai media dakwah, dan sebagai sebuah karya sastra dan seni mengolah bahasa.
\end{abstract}

Kata Kunci: syair Islam; sastra Melayu; Rukun Nasution

\title{
Introduction
}

Islam appreciates the activity of reading significantly, as indicated in the first verses of the Qur'ān received by the Prophet Muhammad (Sürah al-'Alaq/96). The Islamic command to read is associated with the need to develop writing skills. The historical life of the Prophet Muhammad (Sirah Nabawiyyah) records that he communicated with neighboring rulers through writings. The Prophet's command to put the verses of the Qur'ān in writing is also a clear indication of its importance in Islam. During the heyday of Islamic civilization, Muslims represent the most advanced society in letters. Their literary tradition left a significant amount of heritage in different branches of knowledge (Ibn al-Nadīm, 1929; Ḥājj Khalīfah, 1943). Although the biggest part of this heritage was written in prose, some other substantial information on Islam was also recorded in poetry. In Islamic tradition, poetry is used to discuss a variety of fields, such as literature, Islamic Law, ethics, Sufism, Arabic Grammar, et cetera. In 
Islamic Poems by Rukun Nasution (1928-1998) ...

general, poetry is intended to beautify the language, thereby making it readable and easy to remember (Khulūṣī, 1990).

It is only natural that most primary sources on Islam are written in Arabic. However, the Malay language is also important in the Nusantara world, notably after the emergence of some Islamic sultanates in the $13^{\text {th }}$ century. The majority of Nusantara's manuscripts are in Malay, as stated by earlier studies (Braginsky, 1998; Saputra, 1997; Ilyas, 2018; Butar-Butar, 2018). In addition to being used as a lingua franca throughout the region, the Malay language was also used as an intellectual medium of expression (Roza, 2017). Therefore, there is a huge number of manuscripts in Malay that are not only relevant in the time of their production, but also do they carry the potentials to contribute in the present time and the future (Gunawan, 2018). However, irrespective of these attributes, Malay manuscripts have not been accorded the attention they deserved both from the public and the scholarly communities. Therefore, an individual initiative such as the one made by Irwansyah needs to be appreciated (Irwansyah, 2019).

The present research aims to analyze two Islamic poems written in the 1960s, entitled Syair Pengajak Solat and Doa/Syair Menjelang Pajar. This is a preliminary research with data obtained through documentation, description, and introduction of the manuscripts, which have never been studied nor published. Indeed, the poems came to the attention of the present writer only in 2018. This research focuses on explaining 1) Rukun Nasution's background, 2) physical description of the corpus, 3) themes and 4) social relevance of the poems. 


\section{Method}

Essentially, this is a literary study with poems used as objects because a greater attention is given to mapping its content (Endraswara, 2008). This study also involves some social history by considering the poems as a socio-religious phenomenon in its local context. Furthermore, this study considers the various views of Kuntowijoyo (2003, 2008). It also applies some elements of biography studies (Harahap, 2014) and philology (Butar-Butar, 2017) in accordance with the object requirements. Data were obtained from three sources, namely the texts of the poem, informants consisting of the author's children, and villagers of Desa Hajoran where Rukun had spent his entire life. Some secondary sources were also used in the process of data analysis.

\section{Literature Review}

The study of Islamic Malay literature is by no means new; a long list of works on the theme could be produced. Braginsky (1998) provides one of the most comprehensive lists and descriptions of Malay literature. His thick work surveys the theme from $7^{\text {th }}$ to $19^{\text {th }}$ centuries, thus covering almost the whole range of production time of Malay literature. Chambert-Loir (2009) focuses on the history of translation into the Malay language of works mainly from Arabic. Indeed, translation is one of the ways Malay literature is produced. His research provides information about translation procedures as well as the extent of its resulting literature throughout history. Ilyas (2018) provides not only a fairly long list of works by Nusantara scholars, but also the description of their contents. His work could serve as a solid basis for further content-analysis studies. 
Islamic Poems by Rukun Nasution (1928-1998) ...

Ja'far's (2017) study is also of great importance since it elaborates the place of traditional Islamic works in Al Jam 'iyatul Washliyah networks of madrasas. Al Jam'iyatul Washliyah has been a main provider of Islamic education in the region of Northern Sumatra since the 1930s. Despite modernization, its madrasas continue to include traditional Islamic books in the curriculum (Asari, and Tanjung 2019; Asari, and Abidin 2020). Other studies undertaken by particular scholars explained their contribution to knowledge through their works. This type includes, among others, Syahnan (2019) who analyzes the works of Ali Hasan Ahmad ad-Dary, a Southern Tapanuli scholar; Dahlan (2020) who focuses on Zainal Abidin Ahmad, an early $20^{\text {th }}$ century scholar of East Sumatra; and Ja'far (2020) who elaborates on the contribution of Arsyad Thalib Lubis, one of East Sumatra's most productive writers. Roza (2017) explains the ways in which Malay Islamic manuscripts significantly contributed to intellectual achievement of the Nusantara world. Important studies on the aspects of Islamic manuscripts of the neighboring Aceh have been made by Fakhriati (2010a, 2010b, 2013).

The present study focuses on two Malay poems never described or analyzed before in any academic publication. As such, this could be described as a pioneering study that introduces Rukun Nasution's poems to general contemporary readers. However, this study benefits greatly from its predecessors for perspectives as well as methodological insights. 


\section{Result and Discussion}

The results of this study are presented in relation to the relevant previous studies then followed by some discussion.

\section{Rukun Nasution: Birth and Education}

Rukun Nasution was born in 1928 in Desa Hajoran, a small village of sub-district Sungai Kanan, district of South Labuhanbatu, province of North Sumatra. He was the eldest of two brothers and spent two decades of his life in the period when Indonesia was still under foreign occupation - first the Dutch and then the Japanese. As a young adult, Rukun experienced turbulent years following the independence of Indonesia in 1945 . He had very limited education opportunity, because at that time, Hajoran did not even have an elementary school. The first Islamic formal education institution in Hajoran Simaninggir was established in 1958 by Lukmanul Hakim Nasution, Rukun's younger brother. However, his parents managed to enroll him in an elementary school in Langgapayung, the sub-district's main city-some ten kilometers away from home. The paper authors were lucky to find Rukun's original elementary school certificate. Although its condition is far from good, it clearly shows that he completed this school in 1940, at the age of twelve.

Rukun did not attend any other formal education asides from elementary school. However, it is worth noting that completing elementary school was a notable achievement at that particular time and place. Although there was no relevant available statistics, it is easy to see that the majority of Rukun's generation did not attend any formal schooling. Fortunately, the limited schooling enabled him to read and write Arabic (the Qur'ān), Malay and Latin. Rukun had to 
Islamic Poems by Rukun Nasution (1928-1998) ...

stop his formal education at the elementary level in 1940 when Indonesia was under Dutch occupation, which was only two years before the Japanese took over. This period was associated with turmoil in Indonesia, which made it difficult for anyone to achieve formal education. Furthermore, Rukun was not strongly motivated by his parents (especially his mother). This is due to the fact that at that time, parents in Hajoran were concerned that the Japanese military recruited educated children, which proven to be true. Japan's significant involvement in World War II led them into drafting young boys to enlarge its military forces. Rukun was the eldest son and had only a younger brother who further strengthened the emotional tie with his mother. Rukun regretted not being able to continue his formal education. According to his eldest daughter, Rafiah Nasution, he often recalled those days when he motivated his children to strife for their education. He often said, "Pade hamu nasikolai inang, au najolo nasikola au harana masoi zaman panjajahan, oppungmu pe inda dipaksa ia au," in local Mandailing language, which means: "You should always be very serious with education. I did not go to school because of the colonial situation, and your grandmother failed to motivate me."

After being forced to quit formal schooling, Rukun tried to educate himself through non-formal education by attending the majlis ta lim of Ahmad Syekh Abdurrabbi Siregar, a local 'ulamā' who studied under Syekh Sulayman Arrasuli of Candung West Sumatera. Arrasuli was the founder of the Persatuan Tarbiyah Islamiyah, an Islamic organization that develops chains of madrasas in West Sumatra and other regions, including North Sumatra (Asari, 2006). This majlis ta'lìm held some religious activities. Rukun formed the habit of leaving Hajoran every Thursday afternoon on his bicycle and heading to Langgapayung, a 
small town some ten kilometers to the east. After performing afternoon and night congregational prayers (Maghrib and 'Isyā') the syaikh led the group through a night long tawajjuh. The following day on Friday, a more general sermon was held, usually attended by a much larger audience of which do not spend the night at the compound. The sermon went on until around midday and ended when the Friday congregational prayer drew closer. The locals termed this activity "mangaji, tawajjuh, or maramal", which means learning, meditation, or worship. Rukun Nasution frequented this program consistently until his demise. Rafiah Nasution accompanied her father during the final days and stated that he was not ill during his lifetime. In fact, he failed to attend the program only two weeks before his death. Rafiah further stated that Rukun's zeal in attending his non-formal learning was also noted by Aminuddin Syekh Siregar, Syekh Abdurrabbi's son who led the majlis ta 'im by the time of Rukun's death. Aminuddin stressed that habit in his eulogy in Rukun's funeral service. The present paper authors attended the funeral service in person.

In addition to the one in Langgapayung, Rukun also attended another weekly majlis ta'ìm in Hajoran Simaninggir. Villagers in this community usually call such activity markitab, which is loosely translated as reading books (kitab). In this particular village, the majlis ta'lim is based on a book (kitab), read by the guru (a teacher or instructor) and explained to the disciples. The most common subjects of markitab are theology and Islamic law (tawhị d and fiqh), and the most popular book is Kitab Sifat Duapuluh (The Book of Twenty Attributes of God) which contains the foundation of Islamic theological doctrines. Although the title is in Malay, the script was written in Arabic. Since the 1950s the markitab in Hajoran Simaninggir was led 
Islamic Poems by Rukun Nasution (1928-1998) ...

by Lukmanul Hakim Nasution popularly known as Guru Agama or Religious Teacher. Lukmanul Hakim Nasution is Rukun's younger brother. He studied under the guidance of Tuan Guru Ahmad Syekh Abdurrabbi Langgapayung before moving to West Sumatra to study directly under the celebrated Syekh Sulayman Arrasuli, founder of PERTI. In 1983 Ustaz Lukman moved to Rantauprapat, the district city capital, some eighty kilometers away from home. Hasanuddin Siregar, popularly known as Guru Uddin, took over and handled the markitab for some years. At times Ustaz Aminuddin Syekh Siregar of Langgapayung was invited to give some variations.

Rukun Nasution is also known as an industrious reader despite the limited number of available reading materials at that time. After Indonesia gained independence, some books, magazines and papers were sent to Hajoran. Rukun read some popular Islamic magazines of the 1970s, such as Panji Masyarakat and Kiblat. He was also a regular reader of the Bulletin Dakwah published by the Dewan Dakwah Islam Indonesia and distributed bulletins in Hajoran and its vicinities.

\section{Description of the Manuscripts}

The following paragraphs describe the two poems written by Rukun Nasution, namely Syair Pengajak Solat (Invitation to Prayer) and Doa/Syair Menjelang Pajar (Invocation/Poem before Dawn).

\section{Syair Pengajak Solat}

Rukun wrote Syair Pengajak Solat in Malay language. The colophon manuscript available to the authors was a reproduction copy completed on April 4, 1996. The colophon reads as follows "Written in Hajoran Simaninggir on Monday 11-07-1996 and copied to this book in 04-04-1996CE." However, this dating proves 
problematic because of another explanation in the first stanza of the poem as follows.

Satu Ramadan mula manyurat,

Di Simaninggir hari Jumat.

1397 bilangan sanat,

Kertas dawat menjadi surat.

[The first of Ramadan it all begins,

In Simaninggir when the Friday hints,

1397 as the year prints,

Letters are made from paper and inks]

This stanza clearly indicates the beginning of the production of the text, i.e. the first day of Ramadan 1397, using the Islamic Hijri calendar, which corresponded with August 16, 1977. Supposing 'manyurat', which means 'to write' here meant the creative production of the text (not just copying to another medium), the poem is likely to have two dates of production, such as 1969 (according to the colophon) and 1977 (according to the first stanza). Another option is taking 'manyurat' to mean copying - or perhaps recopying-from an older copy to the existing manuscript. However, this would also mean that it took the author two decades (1977-1996) to copy the text. This appears to be unlikely because the poem comprises only forty-one stanzas, thereby making it short.

Presently, there is no additional information available to settle the problem. Nevertheless, it seems that this stanza was an addition to start the copying process. The second stanza of Syair Pengajak Solat is as follows.

Dengan bismillah mula dikata, Menulis sya'ir nama pengajak. Janggal dan salah selalu jumpa, Karena kami ahlinya tidak. [With Bismillah this verse departs, Pengajak be the title of the art,

Odds and wrongs can't be apart, 
Islamic Poems by Rukun Nasution (1928-1998) ...

Be an expert not we art]

This was likely the actual first stanza of Syair Pengajak Solat when it was first composed in 1969. However, it is indeed very unfortunate that the authors do not have this first version at their disposal.

Syair Pengajak Solat was written in the Malay language with Latin script used to apply with a regular pen. The handwriting is normal, without applying any calligraphy techniques. Furthermore, the font is italicized at some 45 degrees and roughly written, with every letter ' a' taking approximately 0.3-0.4 $\mathrm{mm}$ of space. The writing style is very consistent throughout the poem's stanzas. According to Rafiah Nasution, Rukun frequently stated that neatness of handwriting was emphasized greatly at school he attended during the Dutch Colonial times. Therefore, he frequently criticized the quality of his children's handwriting despite their much higher formal education. The paper used is just a regular writing book with guiding lines. Almost the whole space is used for writing, allowing only less than one-centimeter margin to the left and right. The top and bottom margins are in line with the guiding lines.

Syair Pengajak Solat covers seven pages, comprising forty-one stanzas of each marked with a serial number by the poet. The number is positioned to the left of every fourth line of any given stanza.

\section{Doa/Syair Menjelang Pajar}

Doa/Syair Menjelang Pajar is written in the same media, applying the same handwriting style as the Syair Pengajak Solat. This poem does not indicate its time of production or reproduction. Rather it is 
included in the same volume as that of Syair Pengajak Solat hence it is fair to assume that both were produced in 1996.

The poem Doa/Syair Menjelang Pajar consists of twenty-three stanzas written from pages 15 through 18 . Physically, this poem is merely half of Syair Pengajak Solat (41 stanzas) and Jangan Salah Mengikut (47 stanzas). Each stanza is numbered and aligned to the left of every fourth line of any given stanza.

\section{Themes of the Poems}

In the most general sense, the titles of the poems indicated some Islamic themes. The following paragraphs explain the themes in further details.

\section{Syair Pengajak Solat}

The title of this poem explicitly explains its theme by inviting people to prayer (saläh), which is one of the Five Pillars of Islam. Șalāh has always been central to Islamic religious discourse throughout history. Every Muslim is mandated to perform obligatory șalāh five times a day along with some optional ones. Șalāh has always been emphasized not just because of its doctrinal position but also due to the fact that many Muslims fail to perform them consistently.

In explaining prayer, a total number of forty-two stanzas of Syair Pengajak Solat are organized into parts or segments. These thematic parts are of different lengths with some comprising of two stanzas while others are much longer. Stanzas one through three contain the opening and introduction of the poem. The very first stanza explains the time and place of the text's production, as earlier stated. The second and third stanzas include the basmalah 
Islamic Poems by Rukun Nasution (1928-1998) ...

(Abū Dāwud al-Sījistānī, n.d.). Unlike the general practice, here basmalah is followed neither by the hamdallāh nor șalāwat (prayer) to the Prophet Muhammad. Instead, the opening here emphasizes on surrendering oneself solely to Allah. After the basmalah the author proceeds with a statement on his limited knowledge, an apology for any ensuing mistakes and shortcomings, and plea for his readers' forgiveness. Humbling before God and the audience is normal in Islamic literary tradition. It is usually represented by words or phrases before the author's name. For instance, 'this book is the work of such-and-such a person whose knowledge is very shallow,' or 'this book is authored by a servant that is poor and low before Allah.' Many other variations could be found in Ilyas (2018: $98,109,146,230,304,322)$. These phrases are meant to underline the religious dimension of literary production.

Stanzas four through fourteen introduce prayer as the central theme of the poem. This part emphasizes the importance of prayer in Islamic teaching and goes on to underline the difficulties associated with performing the process. The poem takes the dawn prayer $(s u b h)$ as an illustration because it is generally considered the most troublesome out of the five daily prayers. The dawn prayer needs to be performed very early in the morning about one hour before sunset when many prefer sleeping. Stanza seven highlights the function of nakus, which is sounded in mosques to wake neighboring Muslims and at the same time inform them of the coming of dawn prayer time. An informant named Muhammad Daud Nasution stated that in Hajoran and the surrounding villages, the instrument to announce the coming of prayer time is called nakus. This tool is usually made of a log out of a specific very hard tree known as aloban, which is approximately 1,5 meters long with 
a diameter of 0.5 meters. Cavity is made along with the log with some $15-20 \mathrm{~cm}$ opening, which makes it sound louder when hit. Nakus is hung vertically in a minaret and struck with a special bat made of the same wood, some $40-50 \mathrm{~cm}$ long with a diameter of around $5-7 \mathrm{~cm}$. The handle's end is made a bit smaller to allow better grip and enables it to be easily tucked into the nakus's opening and moved horizontally to produce variations of sounds. In Hajoran and the surrounding villages, nakus is sounded twice for every prayer time. The first is called ketek (small), and it is sounded half an hour prior to the actual prayer time. The sound is used to inform people to get ready for prayers. The second sounding marks the actual prayer time, and is immediately followed by azān. Apart from that, nakus also used as an emergency signal in cases of fire, flood, landslides, etc.

The following are stanzas seven and eight of Syair Pengajak Solat:

Sekarang sudah menjelang fajar,

Naqus berbunyi sudah terdengar.

Di dusun dan kota masjid dan langgar,

Menyuruh bangun tinggalkan tikar.

[It is now heading to fajar

Naqus is sounded from afar

In villages, towns and langgar

It asks you all to leave your tikar.

Tinggalkan tikar bangun dan mandi,

Bersihkan badan tangan dan kaki.

Lalulah pergi ke mesjid suci,

Berbuat ibadat seikhlas hati.

[Leave the tikar, up and bath,

Purify body hand feet you hath,

Off to the mosque is your path,

Perform ibadah with a sincere heart]

The author stresses the importance of prayer by referring to the Prophet's popular saying ( $h a d \dot{i} \dot{s})$ as stated in stanza twelve. 
Islamic Poems by Rukun Nasution (1928-1998) ...

Meninggalkan solat bila sengaja,

Menjadi kafir terang dan nyata.

Janganlah syak semua kita,

Hadisnya nabi empunya kata.

[Leaving salah on intention,

Plain and clearly be a deception,

We all should never question,

It is Prophet hadith that mentions]

Stanzas fifteen through sixteen emphasize the importance of having knowledge of prayer and the ability to perform it in line with its requirements and procedures. Stanzas seventeen through twentynine of Syair Pengajak Solat individually delineate the thirteen basic parts of a prayer. Every single act that constitutes a prayer is explained in one stanza. The following are some examples, starting with stanzas sixteen and seventeen.

Solat tertera di depan ini,

Satu demi satu semua rukunnya.

Baca dan fikir renung di hati,

Jangan tertinggal salah satunya.

[Salah is to be explained here,

Its all procedures, one by one.

Use your eyes, mind and ear,

Do not miss even a single one.]

Awal pertama mula dibilang,

Niat yang suci di hatinya terang.

Jangan sekali melarat kenang,

Supaya amalan baik terbilang.

[The very first to be mentioned,

A heart with light and pure intention.

Aim your focus on one direction,

So that your salah be in perfection]

Stanzas twenty-one, twenty-four, and twenty-eight explain the fifth, eighth and twelfth parts of prayer as follows.

Ruku' namanya bilangan ke lima,

Tulang belakang ratalah sama.

Tempat sujud tujuan tiliknya,

Hingga sampai pada bangkitnya. 
[Ruku' to be the fifth order

Back spine rests as flat as water

The sojud be the aiming point

Until it is time to rise again.]

...

Kerja kedelapan yaitu duduk, Namanya itu duduk tawarruk.

Hati di dalam suci dan khusyu',

Sekalian anggota semua tawadlu'.

[To get seated is the eighth act,

Tawarruk the name to be exact.

Heart of pure and remain intact,

All parts of body stay retract.]

Kedua belas memberi salam,

Ke kanan dan kiri buatlah tamam.

Inilah dia kewajiban umat Islam,

Lima kali sehari semalam.

[The twelfth act be the salam,

Turn right and left make a tamam,

This is the duty for men in Islam,

Five time in day and nightime.]

After explaining the parts of prayer, stanzas \#30 through \#34 reemphasize the importance of prayer and the need for Muslims to perform it wholeheartedly. This segment also invokes the popular story of Isrā'-Mi'rāj, which is associated with the Miraculous Ascension of the Prophet Muhammad to Heaven. It is said that initially, God had asked Muhammad and his followers to carry out fifty prayers per day. However, after realizing its difficulties for Muslims, He continuously reduced it to five prayers a day. Therefore, with this praying background in mind, Muslims do not need to consider the act of praying five times a day as a burden.

There is almost no religiously acknowledged reason to skip a prayer, except for women with natural excuses, such as those in their menstruation or parturition periods. For men, there is absolutely no excuse to skip salah. Syair Pengajak Solat emphasizes this in Stanza \#35 to \#38. The final three stanzas 
Islamic Poems by Rukun Nasution (1928-1998) ...

conclude the poem by stressing on the absolute importance of prayer. Stanza number forty cites a well-known quote: 'Pikir dahulu pendapatan \# Sesal akhirat berkepanjangan' [Think the consequences in advance \# Remorse in the Hereafter is no chance]. The standard version of this proverb reads: 'Pikir dahulu pendapatan \# Sesal kemudian tiada berguna' [Think the consequences in advance \# Late remorse is of no chance.] The author therefore turns the proverb into religious by replacing 'late' with 'the Hereafter'. Hence the final stanza reads:

Sekianlah saja kita bernazham, Menazamkan sholat rukun Islam.

Handai shohabat terimalah salam,

Assalamu alaikum, berhenti kalam.

[That will conclude our nazham,

to write salah a pillar of Islam.

To all friends, accept my salām,

Peace be upon you, I rest my kalam]

After this concluding stanza, a colophon reads, "Written in Hajoran Simaninggir on Monday dated 11-07-1969 and was copied into this volume in 04-04-1996M." Of this colophon, some discussion has been provided in the beginning.

\section{Doa/Syair Menjelang Pajar}

Before the actual stanzas of Doa/Syair Menjelang Pajar the authors provide a short note on the activities that need to be carried out upon getting up from one's bed, in preparation for the dawn prayer. The notes prescribed the following.

a. Recite Al-Fätihah, the Opening chapter of the Qur'ān, once.

b. Recite Qulhuallāh, i.e. four short verses of the $112^{\text {th }}$ Chapter of the Qur'ān, three times. 
c. Recite Istighfār , i.e. asking forgiveness from the Almighty, three, five, or seven times. The most common version of the Istighfār is 'Astaghfir Allāh al-'Až̀m'.

d. Recite invocation for wellbeing in this world and the hereafter, to be protected from the Hellfire, and forgiven by the Almighty. The text does not prescribe any specific lines of invocation, rather the most common one reads as follows "Rabbanā ātinā fì al-dunyā hasanah wa-fí al-ākhirah hasanah wa-qina ‘ażāb al-nār," [O, Lord bless us all in this world and in the Hereafter; and save us from the Hellfire]. This very popular invocation is taken directly from Sūrah al-Baqarah verse 201 of the Holy Qur'ān.

These notes come in prose followed by the actual poem, which is marked with stanza's number, to the right of every fourth line. This particular poem does not start with a basmalah rather with an invocation for God's mercy and forgiveness for numerous sins. The first and second stanzas are read as follows.

Ya Tuhanku yaa Allaah ampunilah kami,

Dosa yang banyak sudah terjadi.

Demikian lagi ayah dan ummi,

Anak beranak semua kami.

[My Lord, Allah, please forgive us,

So many sins are upon us,

So did fathers and mothers before us,

So do our offsprings, all of us.]

Ampuni kami kecil dan bosar,

Serta selamat jangan kesasar.

Iman dan taat jangan bertukar,

Berkat syafa'at nabi yang mukhtar.

[Forgive us all the youngs and olds,

Guide us safe in your very hold,

Our faith and devotion should not fold,

Our Prophet's syafaat, the man of gold] 
Islamic Poems by Rukun Nasution (1928-1998) ...

Stanzas three through six contain some lines of invocations, asking Allah's guidance and assistance to avoid sins. Stanzas seven through nine record a sincere gratitude for countless gifts of Allah with a special stress put on human organs, such as eyes, hands, legs, ears, nose, et cetera. They also beg for Allah's guidance that all these body parts be used for the cause of worship.

The next theme is an invocation for Allah to bestow stronger faith to His servants to perform more sincere and consistent acts of rituals as written in stanzas ten through twelve. Stanzas thirteen through fiften ask God's help to be kept away from any sinful deeds despite the numerous worldly temptations. These stanzas point out some examples of sins such as consuming forbidden (harām) food or drink, cursing, cheating, stealing, lying, and gambling. Stanza thirteen goes as follows:

Darilah dosa jauhkan kami, Besar dan kecil malam dan hari. Jangan terpikat di dalam hati, Walau diumpan itu dan ini. [From our own sins, keep us away, Big and small, in night and day. Our hearts should never go astray, Though tempted in any way.]

The following part (stanzas sixteen through nineteen) contains invocation for Allah to bestow a good ending (husn al-khātimah). The final four stanzas i.e. stanza twenty through twenty-three conclude the poem as follows.

Wabillahittaufiqu wal hidayah, Harapan tertuju hanya ke Allah. Yang pengasih lagi pemurah, Wallohu 'alam kami berserah. [Wabillahittaufiqu wal hidayah, All of hopes are aimed to Allah, The Most Gracious, The Most Benevolent, In His knowledge, we surrender.] 
Hingga di sini berhentilah syair,

Kamilah tutup inilah akhir.

Diharap terkabul di hari akhir,

Tetap selamat tiada berakhir.

[This is the end of this verse,

The conclusion that we rehearse.

May be granted on the Final Day,

Be in salvation is what we pray.]

Interestingly, after these stanzas with concluding tones, Doa/Syair Menjelang Pajar has two 'extra' stanzas, which read as follows.

Dengan selamat sampai kesurga,

Diterima Tuhan dengan murahnya.

Kekal selamat dengan sempurna,

Menerima ni'mat Allah ta 'ala.

[Arrived in Heaven safe and sound,

Welcome by Allah so profound.

Eternally safe in perfection,

Receiving the Almighty blessing]

Ni'mat diterima tiada hentinya,

Selama masa di dalam surga.

Menambah cocok dilihat dirasa,

Di saban hari tiada hentinya.

[Blessing is received incessantly,

During the Heaven time of eternity.

Abundant to feel, abundant to see,

As each and every day it would be.

As earlier indicated, Stanza twenty-one naturally serves as the ending of the poem. However, the two extra stanzas have substantive relationships with the earlier one. The twenty-two is related to the stanza twenty-one through the concept of salvation (selamat). Similarly, the stanza twenty-three is related to the stanza twenty-two through the concept of favor (ni'mat). Therefore, special notes need to be made regarding the stanza twenty-three, which has different handwriting from others. The words are italicized in a rather wider degree that makes them look almost vertical. Also, the average size of the letters is smaller than the rest. 
Islamic Poems by Rukun Nasution (1928-1998) ...

In addition, this stanza twenty-three is not numbered by the poet, while all other stanzas are numbered in every fourth line. Currently, there is no satisfactory explanation regarding the presence of this stanza. However, in a rather speculative manner and judging from the handwriting, Rafiah Nasution, the eldest daughter of Rukun, proposes the idea that it was probably a very late addition made by the end of the poet's life.

\section{The Social Relevance of the Poems}

It can be said that the themes of Rukun's poems are simply and plainly bear the foundational teachings of Islam. It seems that his poems are meant for ordinary Muslims with limited education. However, we need to examine the relevance of these poems to the society from which these poems were produced. In examining Rukun's poems, we contend that they were produced as a text of religious knowledge, media in the propagation of Islam, and as a form of art.

1. The poems as religious knowledge text

Although Rukun's poem does not resemble a complex structure and form, every writing contains and tries to convey some strong ideas and messages. Upon mapping poems' contents, the authors found that these poems explain some foundational aspects of Islamic teachings in a rather general sense. The bigger part of the poems portrays about salah and the correct way of performing it. Surely, salah one of the essential parts of Islam. Therefore, these poems have documented and stored a very important knowledge about Islam. According to some sources, the contents of the poems are in line with the general practice of Muslims in Hajoran and the surrounding areas. 
The poems' rudimentary nature is explained by the author's educational background, which was only elementary schooling. Rukun's knowledge of Islam is largely based on non-formal learning through majlis ta'tim and reading Islamic bulletin and magazines such as Kiblat and Panji Masyarakat. As such, Rukun was not to be confused with trained 'ulama ' that are generally graduated from pesantren.

2. The poems as Islamic propagation media

According to Rukun's son, Muhammad Daud Nasution, Rukun's poems were often recited with a certain rhythm in a mosque located at Hajoran Simaninggir. The recitation usually took place before the Maghrib prayer and usually lasted from a quarter to half an hour. The mosque ta'mir used the mosque's amplifier device to sound it throughout the village. In Hajoran, this recitation is popularly known as tarahem, which is a local way of pronouncing the Arabic word tarāhim. This activity was called tarahem because it involves the repetition of the phrase 'Yā arhamar rāhimīn, irhamnā ...' which means 'O The Most Merciful, have mercy on us ...'. There seems to be no strict rule regarding what needs to be recited in a tarahem. In practice, the recitation includes verses from the Qur'ān, praises to Allah and the Prophet Muhammad, prayers or invocations, or any composition that contains religious values. A source of this research confirms that the poems of Rukun were often recited in the village mosque. The source stressed that besides Rukun, a village imam named Abdul Manan Siregar also frequently read religious poems in the mosque. 
Islamic Poems by Rukun Nasution (1928-1998) ...

The propagation effect of tarahem grew significantly when the amplifier device was introduced in mosques and widely used for calling for prayers, the tarahem, sermons, and other religious activities. The present authors have not been able to establish the exact date the village mosque of Hajoran Simaninggir started to use an amplifier. However, in 1982 it bought one and started using it for its various activities. At that time, the most popular brand of amplifier was 'Toa.' According to Muhammad Daud Nasution, this brand was dominant and popular. With this sound device, any announcement from the mosque was heard in the whole village and the surrounding farms where most of the villagers spend their time during the day.

\section{The poems as an art}

In principle, poetry is a form of art, in which a poem is an artistic arrangement of words into sentences and stanzas. A poem is not just a game of words, phrases or sentences, rather it carries meanings that a poet intends to record and communicate to the audiences. Therefore, a poet has to tackle both sides to form a meaning.

Conventional poems are composed on either 'aa-aa' or 'ab-ab' rhythm. The first pattern means that every line of a given stanza ends with the same letter or sound. The second pattern means that the first and third lines end with the same letter or sound as well as the second and the fourth line. In composing poems, Rukun Nasution applied the 'aa-aa' rhythm with very small exceptions, as shown in Table 1.

Table 1. Distribution of Stanzas Based on Rhythms 


\begin{tabular}{llll}
\hline No & Poems Title & $\begin{array}{c}\text { Stanzas with 'aa- } \\
\text { aa' Rhythm }\end{array}$ & $\begin{array}{c}\text { Stanzas with } \\
\text { 'ab-ab' Rhythm }\end{array}$ \\
\hline $\mathbf{1}$ & Syair Pengajak & $1,3,4,5,6,7,8,9,2,16,34$ \\
& Solat & $10,11,12,13,14$, \\
& & $15,17,18,19,20$, \\
& & $21,22,23,24,25$, \\
& & $26,27,28,29,30$, \\
& & $31,32,33,35,36$, \\
& & $37,38,39,40,41$ \\
& & $1,2,3,4,5,6,7,8$, \\
& Doa/Syair & $9,10,11,12,13$, \\
& Menjelang & $14,15,16,17,18$, \\
& Pajar & $19,20,21,22,23$, \\
& &
\end{tabular}

The dominance of 'aa-aa' style is clearly seen. In the case of Doa/Syair Menjelang Pajar, $100 \%$ of its stanzas are written in 'aa-aa' style. In poem Syair Pengajak Solat three out of forty-seven stanzas are in 'abab' style, stanza \#2, \#16 and \#34. This consistency demonstrates the ability of the poet to select and arrange words into stanzas that convey his intended messages in a well-structured manner.

\section{Discussion}

The previous section has discussed the data and findings of this study. The following segmen is dedicated to discussing some of the most interesting points of these findings.

First, there is no special interest in the writing medium used by Rukun Nasution in writing those poems. The paper used as media is a regular notebook easily found during the time of production of the manuscript. In fact, the same type of notebook is widely used by school students at that time. However, the manuscript is extremely neat and consistent in style throughout the pages. It is also striking that there is a uniformity 
Islamic Poems by Rukun Nasution (1928-1998) ...

of the size of letters and the degree of italicization. Some informants stated that elementary education during the colonial time had a heavy emphasis on the ability to write neatly. The present authors who had an earlier stage of education in Hajoran and was taught by teachers with contemporary knowledge of Rukun, confirm that teachers at the time had excellent handwriting.

The fact that Rukun produced such poems despite his educational background is an interesting achievement. Authors of Islamic texts usually belong to the educated class. In the Indonesian context, the majority are graduates of pesantrens that are well versed in the Islamic disciplines. Many of the authors of Malay Islamic texts have some additional education in centers of learning in the Middle East. This has been well established by former studies, such as those of Braginsky (1998), Azra (1994), Ilyas (2018), and Butar-Butar (2018). Unlike those authors, Rukun did not have education opportunities except for elementary school. Rukun was known as a regular reader of some Islamic magazines such as Panji Masyarakat, Kiblat, and Buletin Dakwah. Furthermore, he regularly attended different majlis ta'lim in his home village and the surrounding areas. Even after considering all these, his creativity and productivity are rather exceptional.

When these poems are put in their social context, they seem unique. In the 1970s Hajoran Simaninggir district of Labuhanbatu Selatan was inhibited by some forty households only. As far as the available data during the 1960s and the 1970s, this district was by no means strong in formal Islamic education to support literary tradition. The neighboring district of Padang Lawas Utara is the one that houses numerous pesantrens and other traditional Islamic religious learning centers. Moreover, even in regions with a strong presence of pesantren, such as 
Padang Lawas and Mandailing Natal, literary tradition does not necessarily flourish. It was Prof. Abbas Pulungan and Prof. Haidar Daulay, two experts on the history of Islamic Education in North Sumatra who carried out this analysis. They both note that the region did not have a strong writing tradition. In fact, most top flight 'ulama' of the Southern Tapanuli are not known to produce any substantial writings, with a few exceptions. For instance, Ilyas' study listed some Southern Tapanuli's 'ulamā' that left important works, such as Abdul Qadir ibn Shabir, Baharuddin Thalib Lubis, Arsyad Thalib Lubis, Abdul Qadir Muthalib, and Yusuf Ahmad Lubis (Ilyas 2018; Ja'far 2020). More recent studies explore other writers such as Ali Hasan Ahmad ad-Dary (Syahnan, 2019) and Zainal Arifin Abbas (Dahlan, 2020). With this social-intellectual background, it is fair to conclude that Rukun Nasution's poems are unique and somehow anomalistic.

Secondly, the themes of the poems are rather general and foundational, namely theology, Islamic law of rituals, and some ethics with sufism tinge. Rukun's poems are intended for general layman readers who wish to strengthen one's belief in Allah without doubting Islamic teachings. Furthermore, there are prolonged explanations on the thirteen parts of the prayer (salāh), including the proper way of performing each. The poems also include an invitation to ponder upon the favors given by Allah in the form of an ideal human body with complete functioning parts. In order to express their gratitude, those body parts need to be used in ways approved by Islamic teachings.

The poet also urged on the importance of continuous improvement of religious knowledge of every Muslim. Knowledge is indispensable; Islamic teachings are practiced correctly only when one acquires a sufficient amount of knowledge. In other words, these poems are 
Islamic Poems by Rukun Nasution (1928-1998) ...

intended as means of propagation, inviting Muslims to become better informed and, at the same time, more obedient to Allah. At many points, the poems emphasized the idea of Allah as the Merciful lifegiver that provides humans with limitless favors. Humans are always indebted to Allah for His borderless mercy and limitless favors, and obedience is the only proper response. However, the author does not fail to realize that life presents many challenges and temptations that cause deviation from the straight path of Islam. Therefore, the poems play a double-sided function, one side is as information for the uninformed, and the other side is as a reminder for the negligent.

Finally, the process of conveying ideas through poems is not new in Muslim intellectual tradition. In fact, it has been carried out throughout Islamic history, and examples are easily available. Some of the most popular poems include, the Alfiyyah by Jamāl al-Dīn ibn Mālik on Arabic grammar; the Qașīdat al-Șiyām wa al-Zakāt, by Abān ibn `Abd al-Ḥāmid al-Lāhịiqi on laws of fasting and alms, the Urjūzat al-Hajj, by Aḥmad 'Īsā Radā'̄ on laws of the pilgrimage, the celebrated Rubā 'iyyāt, by 'Umar al-Khayyām on sufistic literature, the Raqm alHulal fì Naẓm al-Duwal, by Lisān al-Dīn al-Khațīb on Islamic history, and the `Iqd al-Jawāhir, by Ja `ar al-Barzanjī on the life of the Prophet Muhammad saw. Apart from those independent poetic works, long or short, countless poems containing religious knowledge found in different non-literary books. One of such books is the Mu jam alBuldān by Yāqūt al-Hamawī (1900), which is basically on geography.

Poems as a mode of expressing religious knowledge are found in all major Muslim languages. In the Indonesian context, the Malay language was the lingua franca when the region was under the Islamic kingdoms, therefore it was used for every aspect of life, including in 
religious propagation and education. Rukun's poems fall into the genre of didactic poems (syi 'r ta limmī), with the core objective of teaching a body of knowledge to improve its readers' religious consciousness and piety. Such a genre of poem is significantly found in Arabic. According to Șafā' Khulūṣī (1990: 498):

Arabic didactic verse (syi 'r ta 'limmi) solely aims at teaching a particular genre of knowledge. Many Arab critics do not regard it as true poetry because it is devoid of emotion and imagination, both of which are essential constituents of poetry, besides metre and rhyme. In other words, they consider it a versified prose.

The didactic verse is instructive, in adding to one's knowledge and aims at improving one's moral. It pleases the ear and aids memory.

Hajoran, the village where Rukun produced poems, is inhabited mainly by Mandailings emigrants, therefore their language is used in their day-to-day activities. However, in religious activities the Malay language is more commonly used. This is indicated in local pesantrens in which Arabic books are translated into Malay rather than Mandailing language (Rasyidin, 2017: 61). This practice is different from the practice of pesantrens in Java, where translating Arabic books into Javanese is popular (Nasution, 2020: 135). During the Friday congregational prayer, the sermon (khutbah) is normally delivered in Malay language, based on a kitab entitled Wahy al-Minbar by acertain Muhammad 'Alī al-Hamīdī. The same is true in the case of Islamic festivities, such as 'Īd al-Fițī̄, 'Īd al-Aḍhạā, the Prophet's birthday celebration, et cetera.

These poems of Rukun have never been published. The present authors are not aware of the existence of any other copy of the poems other than the ones at their disposal. However, since they were recited 
Islamic Poems by Rukun Nasution (1928-1998) ...

through the village mosque's minaret, their messages were to some extent known to the villagers.

It has been mentioned that Rukun responded to the emergence of fake 'ulam $\bar{a}$ '. The awareness of this phenomenon needs to be shared with many Muslims, especially by the learned segment. The poet is unique in a way he realized that complex social phenomenon, but conveyed his message in a rather simple technique, i.e. by composing poems. Rukun's criticism of such 'ulamā' followers do not involve sophisticated arguments and religious interpretation. He simply asks people to exercise carefulness in choosing whom to follow for matters of religion. People need to take every precaution before deciding to become part of a new emerging Islamic group. Rukun's criticism and advice are general in nature because he had no expertise in Islamic knowledge. He positions himself merely as a concerned Muslim, recording some observations and presenting some pieces of advice. This can be seen in opening stanza of Syair Pengajak Solat cited earlier.

Dengan bismillah mula dikata, Menulis syair nama pengajak. Janggal dan salah selalu jumpa, Karena kami, ahlinya tidak.

[With Bismillah this verse departs,

Pengajak be the title of the art, Odds and wrongs can't be apart, Be an expert not we art.]

Rukun is known as a person with strong social awareness and always tries to contribute in any way possible. His villagers remember him as a practicing Muslim and an ever-contributing member of their society.

\section{Conclusion}


In principle, the poems studied here do not present any sophisticated philological issues. Rather, all texts are produced in recent times, i.e. the second half of the $20^{\text {th }}$ century, and written in Latin, thereby deviating from the more popular practice of using Malay-Arabic scripts for such genre of literature. The media on which the poems are written is also regular and readily available in the general market as a 50 -gram notebook with guiding lines. Furthermore, the handwriting is very neat and consistent throughout the poems in both sizes, with the letters italicized. An absolute majority of the stanzas are written in 'aaaa' rhythm.

As indicated by their titles, the poems contain Islamic information with the most dominant theme being salah, its parts/acts, and the way to perform them correctly. The poems of Rukun are socially relevant from at least three perspectives. Firstly, it serves to record and preserve Islamic knowledge and information. Secondly, it functions as media of Islamic propagation with valuable information documented, preserved, and made accessible to others. Indeed, it is regretful that they have never been published during the lifetime of the poet. Thirdly, they are relevant as a linguistic art, following a long tradition of putting Islamic information into stanzas. These poems are a product of high linguistic capacity, indicated by excellent word choices, the arrangement of phrases into stanzas, and its organization into well-structured poems.

\section{References}

Abū Dāwud al-Sījistānī. n.d. Sunan Abī Dāwud. Beirut: al-Maktabah Al-`Așriyyah.

Asari, Hasan and Abidin, Zainal. (2020). "Kitab Kuning and Training of 'Ulamā': The Experience of Madrasah Al Qismul Ali Jalan 
Islamic Poems by Rukun Nasution (1928-1998) ...

Ismailiyah Medan." Miqot: Jurnal Ilmu-Ilmu Keislaman 44(1):93-115. doi: 10.30821./miqot.v44i1.750.

Asari, Hasan and Tanjung, Muaz. (2019). "History of Maktab AlIslamiyah Tapanuli." Heritage of Nusantara 9(2):297-334.

Asari, Hasan. (2006). Menguak Sejarah Mencari 'Ibrah: Risalah Sejarah Sosial-Intelektual Muslim Klasik. cet. 1. Bandung: Citapustaka Media.

Azra, Azyumardi. (1994). Jaringan Ulama Timur Tengah dan Kepulauan Nusantara Abad XVII dan XVIII: Melacak AkarAkar Pembaruan Pemikiran Islam Di Indonesia. Bandung: Mizan.

Braginsky, V. I. (1998). Yang Indah, Berfaedah dan Kamal: Sejarah Sastra Melayu Dalam Abad 7-19. Trans. Hersri Setiawan. Jakarta: INIS.

Butar-Butar, Arwin Juli Rakhmadi. (2017). Filologi Astronomi. Purwokerto: UMP Press.

Butar-Butar, Arwin Juli Rakhmadi. (2018). Mengenal Karya-Karya Ilmu Falak Nusantara: Transmisi, Anotasi, dan Biografi. Yogyakarta: Arti Bumi Intaran.

Chambert-Loir, Henri (ed.). (2009). Sadur: Sejarah Terjemahan di Indonesia dan Malaysia. Jakarta: Kepustakaan Populer Gramedia.

Dahlan, Zaini. (2020). "The Intellectual Tradition of Mandiling Ulama in East Sumatra: Zainal Arifin Abbas, 1912-1979." Journal of Contemporary Islam and Muslim Societies 4(1):23-57. doi: 10.30821/jcims,v4i1.7025.

Endraswara, Suwardi. (2008). Metodologi Penelitian Sastra: Epistemologi, Model, Teori Dan Aplikasi. Yogyakarta: MedPress.

Fakhriati. (2010a). "An Overwhelming Heritage of Manuscripts in Pidie and Aceh Besar Regencies." Jurnal Lektur Keagamaan $8(1): 31-46$.

Fakhriati. (2010b). "New Light on the Life and Works of Teungku di

94 | VOL. 10 NO. 1 JUNE 2021 
Pulo an Acehnese Intellectual in the Late 19th and Early 20th Centuries." MIQOT: Jurnal Ilmu-Ilmu Keislaman 34(1):23-38. doi: 10.30821/miqot.v34i1.184.

Fakhriati. (2013). "The Use of Papers in the Acehnese Islamic Manuscripts and Its Historical Context." Heritage of Nusantara 2(1):51-72.

Gunawan, Aditia dan Ali Akbar (ed.). (2018). Naskah Nusantara Antara Kekunoan Dan Kekinian. Jakarta: Masyarakat Pernaskahan Nusantara dan Perpustakaan Nasional.

Ḥājj Khalīfah, Musțafā ibn ‘Abdillāh. (1943). Kasyf Al-Ẓnūn ’an Asāmī Al-Kutub Wa Al-Funūn. Istanbul: al-Ma`ārif.

Harahap, Syahrin. (2014). Metodologi Studi Tokoh \& Penulisan Biografi. Jakarta: Prenada.

Ibn al-Nadīm, Muhạammad Abū al-Faraj. (1929). Kitāb Al-Fihrist. Cairo: al-Maktabah al-Raḥmāniyyah.

Ilyas, Ahmad Fauzi. (2018). Warisan Intelektual Ulama Nusantara: Tokoh, Karya, Dan Pemikiran. Medan: Rawda Publishing.

Irwansyah, Dedi. (2019). "Islamic Literature: Instructional Strategies in Contemporary Indonesia." Heritage of Nusantara 8(1):1-17. doi: 10.3129/hn.v8i1.548.

Ja'far. (2017). "Khazanah Kitab Kuning di Madrasah Al Jam'iyat Al Washliyah." Jurnal Al-Thariqah 2(2):124-34. doi: 10.25299/althariqah.2017.vol2(2).1041.

Ja'far. (2020). "Peran M. Arsyad Th. Lubis Dalam Pengembangan Ilmu-Ilmu Keislaman.” Dialogia 18(2):355-76. doi: 10.21154/dialogia.v18i2.2216.

Khulūṣī, Șafầ. (1990). "Didactic Verse." in Religion, Learning, and Science in the 'Abbasid Period, edited by and R. B. S. (eds.) M. J. L. Young, J. D. Latham. Cambridge: Cambridge University Press.

Kuntowijoyo. (2003). Metodologi Sejarah. Yogyakarta: Tiara Wacana. 
Islamic Poems by Rukun Nasution (1928-1998) ...

Kuntowijoyo. (2008). Penjelasan Sejarah (Historical Explanation). Yogyakarta: Tiara Wacana.

Nasution, Lahmuddin. (2020). Menjaga Tradisi Mengawal Modernitas. Medan: Perdana Publishing.

Rasyidin, Al. (2017). "Pembelajaran Kitab Kuning di Pesantren Musthafawiyah, Mandailing Natal." Journal of Contemporary Islam and Muslim Societies 1(1):41-67.

Roza, Ellya. (2017). "Aksara Arab-Melayu di Nusantara dan Sumbangsihnya Dalam Pengembangan Khazanah Intelektual." Tsaqafah: Jurnal Peradaban Islam 13(1):177-204. doi: 1021111/tsaqafah.v13i1.982.

Saputra, Karsono H. (ed.). (1997). Tradisi Tulis Nusantara. Jakarta: Masyarakat Pernaskahan Nusantara dan Perpustakaan Nasional.

Syahnan, Mhd. (2019). "Nahdlatul Ulama Scholar in Mandailing Land: A Biography of Shaykh Ali Hasan Ahmad Ad-Dary." Journal of Contemporary Islam and Muslim Societies 3(1):68-82. doi: 10.30821/jcims,v4i1.7025.

Yāqūt al-Hamawī, Syihāb al-Dīn. (1900). Mu`jam Al-Buldān. Beirut: Dār Șādir. 